\title{
FIRST RECORD OF A FISH PARASITE APOROCOTYLE SIMPLEX (DIGENEA) FROM THE POLISH EXCLUSIVE ECONOMIC ZONE OF THE BALTIC SEA
}

\author{
Leszek ROLBIECKI*
}

\author{
Division of Invertebrate Zoology, University of Gdańsk, Poland
}

Rolbiecki L. 2007. First record of a fish parasite Aporocotyle simplex (Digenea) from the Polish Exclusive Economic Zone of the Baltic Sea. Acta Ichthyol. Piscat. 37 (2): 95-97.

\begin{abstract}
One specimen of Aporocotyle simplex Odhner, 1900 (Digenea: Sanguinicolidae) was confirmed in 2004 from the branchial artery of a dab, Limanda limanda (Linnaeus, 1758), from the Gulf of Gdańsk. This work provides a partial description and a few morphological measurements of that specimen. This is the first record of A. simplex from Poland.
\end{abstract}

Keywords: Sanguinicolidae, fish blood fluke, Limanda limanda, dab, fish, parasite, Gulf of Gdańsk, Poland

The range of dab, Limanda limanda (Linnaeus, 1758) (Actinopterygii: Pleuronectidae) covers the European Atlantic coasts and stretches into the Polish Exclusive Economic Zone of the Baltic Sea. There are only two Polish publications dealing with parasites of dab (Markowski 1933, Rolbiecki 2004).

In 2004, nine dab specimens (221-224 mm, 154-197 g) were captured from the Gulf of Gdańsk, Poland and examined for parasites. One live specimen of Aporocotyle simplex Odhner, 1900 (Fig. 1), infecting the branchial artery of the second gill arch, was recovered. The parasite was preserved in hot $70 \%$ ethanol, stained with Gowers alum carmine, dehydrated in $90 \%$ acetic acid, cleared in benzyl alcohol, and mounted in Canada balsam. It was deposited in the Division of Invertebrate Zoology, University of Gdańsk. This is the first record of $A$. simplex in Poland.

Description and measurements of Aporocotyle simplex (all measurements in $\mathrm{mm}$ ). Body fusiform with anterior end more pointed than posterior end. Body length $2.37 \times 0.44$. Oesophagus 0.74 long, with the glandular posterior part with oesophageal gland cells measuring 0.17. Alimentary tract $\mathrm{H}$-shaped, anterior- and posterior caeca 0.38 and 1.55 long, respectively. Number of testes 131 , measuring $(n=20) 0.016-0.058 \times 0.025-0.058$ (average $0.043 \times 0.036)$, between posterior caeca. Cirrus sac pyriform, recurvate with visible internal seminal vesicle and pars prostatica, submediall, beneath testes; cirrus sac $0.135 \times 0.109$. Ovary oval, submediall, orienting diagonally and opposite of cirrus sac; ovary $0.16 \times 0.13$. Uterus strongly plicate, between cirrus sac and posterior edge of testes and ovary. Uterine seminal receptacle posterior to and slightly lateral of ovary, $0.093 \times 0.051$. Vitelline fol- licles lateral to oesophagus and intestine, terminating at level of ovary. Excretory bladder not observed.

This specimen corresponds to previous descriptions (e.g., Thulin 1980a). Specimens of Aporocotyle simplex infecting dab are shorter than those infections American plaice, Hippoglossoides platessoides (Fabricius, 1780). Based on the published literature the vitelline follicles in specimens of $A$. simplex from dab should be less developed than those from American plaice (Thulin 1980a, 1991), but the present specimen had vitelline follicles that are well developed and surrounding the intestine.

Adults of Aporocotyle simplex mature in the blood vascular system, mainly branchial vessels, heart, and ventral aorta, of flatfishes (Pleuronectidae and Scophthalmidae). The range of the parasite covers the Arctic-, north Atlantic, and the north Pacific oceans. The majority of the host records are from American plaice and dab, but the parasite also infects flathead sole, Hippoglossoides elassodon Jordan et Gilbert, 1880; Atlantic halibut, Hippoglossus hippoglossus (Linnaeus, 1758); Greenland halibut, Reinhardtius hippoglossoides (Walbaum, 1792); flounder, Platichthys flesus (Linnaeus, 1758); witch, Glyptocephalus cynoglossus (Linnaeus, 1758); and European plaice, Pleuronectes platessa Linnaeus, 1758 (cf. Thulin 1980b). A. simplex has also been recorded in a representative of Scophthalmidaeturbot, Psetta maxima (Linnaeus, 1758) (cf. Køie and Petersen 1988). Additionally, Grabda (1977) recorded A. simplex in Alaska pollock, Theragra chalcogramma (Pallas, 1814), while Zubčenko (1981) did so in roundnose grenadier, Coryphaenoides rupestris Gunnerus, 1765; however, Thulin (1980a) suspected that these specimens were Aporocotyle theragrae Ichihara, 1970 based on the hosts'

\footnotetext{
* Correspondence: Dr Leszek Rolbiecki, Katedra Zoologii Bezkręgowców, Uniwersytet Gdański, Al. Piłsudskiego 46, 81-378 Gdynia, Poland, phone: +48 58 523 6638, fax: +48 58523 6630, e-mail: lrolbiecki@ocean.univ.gda.pl
} 


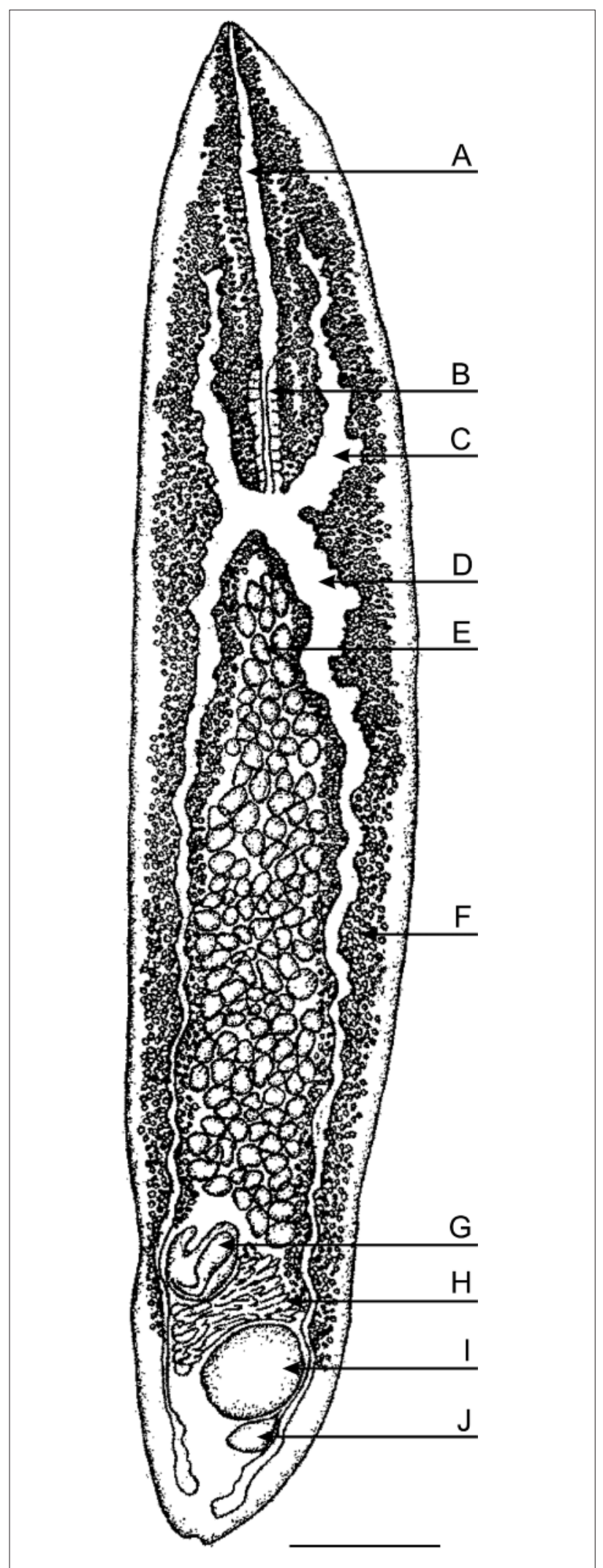

Fig. 1. Aporocotyle simplex from branchial vessels of dab, Limanda limanda, from the Polish Baltic Sea, scale bar $=200 \mu \mathrm{m}$; A: oesophagus, B: posterior part of oesophagus with gland cells, C: anterior caecum, D: posterior caecum, E: testes, F: vitelline follicles, G: cirrus sac, H: uterus, I: ovary, J: uterine seminal receptacle phylogenetic affiliation (Gadiformes) and geographic locality (Pacific Ocean). Indeed the Grabda's (1977) mistake was acknowledged by Grabda (1991), who amended the previous parasite's identification as $A$. theragrae.

Blood flukes, including Aporocotyle simplex, can harm the host fish by damaging the gills and consequently compromise the respiration. Adults and eggs can occlude blood vessels, leading to thrombosis, hyperplasia, epithelium hypertrophy, and, consequently_-gill necrosis. Infected, fish can have granulomatous nodules in the branchial cavity epithelium and the heart of infected fishes can have cercariae and/or schistosomule larvae (Thulin 1991).

Aporocotyle simplex is a marine species using either of the terebellid polychaetes Artacama proboscidea Malmgren, 1865 or Lanassa nordenskioeldi Malmgren, 1866 as intermediate hosts (Køie 1982, Køie and Petersen 1988), and flatfishes as the most commonly reported definitive host (Thulin 1991). Due to the lack of those species of polychaetes in the Baltic Sea would seem that the fluke using another annelids in that area, or A. simplex was introduced here in dab from the region of the North Sea.

\section{REFERENCES}

Grabda J. 1977. Studies on parasitisation and consumability of Alaska pollack, Theragra chalcogramma (Pall.). Acta Ichthyologica et Piscatoria 7 (2): 15-34.

Grabda J. 1991. Marine fish parasitology, an outline. PWN-Polish Scientific Publishers, Warszawa and VCHVerlagsgesellschaft $\mathrm{mbH}$, Weinheim.

Køie M. 1982. The redia, cercaria and early stages of Aporocotyle simplex Odhner, 1900 (Sanguinicolidae) — a digenetic trematode which has a polychaete annelid as the only intermediate host. Ophelia 21: 115-145.

Køie, M., Petersen M.E. 1988. A new annelid intermediate host (Lanassa nordenskioeldi Malmgren, 1866) (Polychaeta: Terebellidae) for Aporocotyle sp. and a new final host family (Pisces: Bothidae) for Aporocotyle simplex Odhner, 1900 (Digenea: Sanguinicolidae). Journal of Parasitology 74: 499-502.

Markowski S. 1933. Die Eingeweidewürmer der Fische des polnischen Balticums (Trematoda, Cestoda, Nematoda, Acanthocephala). Archives d'Hydrobiologie et d'Ichthyologie, Suwałki 7: $1-58$.

Rolbiecki L. 2004. Can the dab (Limanda limanda) be a paratenic host of Anguillicola crassus (Nematoda; Dracunculoidea)? The Gulf of Gdańsk and Vistula Lagoon (Poland) example. Wiadomości Parazytologiczne 50: 317-322.

Thulin J. 1980a. A redescription of the fish blood-fluke Aporocotyle simplex Odhner, 1900 (Digenea, Sanguilicolidae) with comments on its biology. Sarsia 65: 35-48.

Thulin J. 1980b. Scanning electron microscope observations of Aporocotyle simplex Odhner, 1900 (Digenea: Sanguinicolidae). Zeitschrift für Parasitenkunde 63: 27-32.

Thulin J. 1991. Aporocotyle simplex, a blood fluke in flatfish. ICES identification leaflets for diseases and parasites of fish and shellfish. Leaflet No. 49.

Zubčenko A.V. [Zubchenko A.V.] 1981. Ispol'zovanie parazitologičeskih dannyh dlâ izučeniâ lokal'nyh gruppirovok 
tuporylogo makrurusa Coryphaenoides rupestris Gunner). [Using of parasitologic data in studying of rock grenadier (Coryphaenoides rupestris Gunner) local groupings.] Pp. 25-32. In: Symposium on parasitology and pathology of marine organisms, Leningrad, 13-16 October 1981. Nauka, Leningrad. [In Russian.]
Received: 9 July 2007

Accepted: 16 September 2007

Published electronically: 30 November 2007 